\title{
Okul Sosyal Hizmeti Perspektifinden Lise Öğrencilerinin Akademik Başarı Düzeylerinin Farklı Değişkenler Açısından İncelenmesi
}

\author{
Ali Riza ABAY ${ }^{1}$ \\ Fikri KELEŞOĞLU²
}

\section{Özet:}

$\mathrm{Bu}$ araştırmanın temel amacı, lise kademesindeki öğrencilerin akademik başarı düzeylerini bazı değişkenler açısından incelemektir. Bunun yanı sıra, akademik yönden başarısız öğrencilere bu değişkenler dikkate alınarak okul sosyal hizmeti olarak neler sunulabilir bunu tartışmaktır.

$\mathrm{Bu}$ araştırma, 2013-2014 eğitim öğretim yılında Bursa ili Gemlik ilçesinde bulunan M.E.B.'e bağlı 7 tane ortaöğretim (lise) kurumunda öğrenim gören, her sinıf kademesinden random yöntemi ile seçilerek oluşturulmuş toplam 665 kişilik öğrenci örneklem grubu ile yürütülmüştür. Veri toplama arac1 olarak, araştırmacı tarafından hazırlanmış Kişisel Bilgi Formu kullanılmıştır. Verilerin analizinde SPSS 21.0 istatistik programı kullanılmış, elde edilen bulgular için tablolar oluşturulmuş ve yorumlanmıştır.

Analiz sonucunda, öğrencilerin akademik başarı düzeyleri ile cinsiyet, sınıf kademesi, anne babaların evlilik durumu ve kardeş sayısı değişkenleri arasında anlamlı bir ilişki olduğu görülmüştür. Öğrencilerin akademik başarı düzeyleri ile ailede engelli birisi olup-olmama durumuna göre anlamlı bir ilişki bulgulanmamiştır.

Anahtar Kelime: Akademik Başarı, Sosyal Destek, Okul Sosyal Hizmeti.

1 Prof.Dr.,Yalova Üniversitesi İIBF, Sosyal Hizmet Bölümü Öğretim Üyesi, alirizaabay@gmail.com

2 Doktora Öğrencisi, Yalova Üniversitesi, Sosyal Bilimler Enstitüsü, Sosyal Hizmet Bölümü, fikrikelesoglu55@gmail.com 
$10 \cdot$ YALOVA SOSYAL BILIMLER DERGISI

Investigate The Levels Of Academic Achievement Of High School Students In Terms Of Some Variables From The Perspective School Social Work

\begin{abstract}
:
The main purpose of this study is investigate the levels of academic achievement of high school students in terms of some variables. On the other hand, it is aimed to find out what kind of school social work could be given to academically unsuccessfull children.

This research was conducted as a descriptive field research based on scanning model. The sample group consisted of 665 studends chosen randomly from all classes from 7 high schools in Bursa city Gemlik town in 2013-2014 education term. As a means of data collection,Personal Information Form prepared by the researcher were used. SPSS 21.0 statistical software used to analyze the data and from the findings tables and interpretations were created.

As a result of analysis, it was observed that sex, class level, parents' marital status and number siblings with the level of students'academic achievements was found to be a significant relationship between these variables. It was observed that there is not significant relationship between academic achievement levels of students and whether there is disabilities on family.
\end{abstract}

Keywords: Academic Achievement, Social Support, School Social Work

\title{
Giriş
}

Toplumun sahip olduğu tüm değerler ve birikimler eğitim aracılığı ile bireylere geçer. Bu açıdan eğitim, her toplumda yadsınamaz bir öneme sahiptir. Nitelikli insan gücünü, topluma sunabilmenin tek yolu, asırlar geçse de yine eğitim ile mümkün olabilmekte ve eğitim ile toplum menfaatine fayda sağlanabilmektedir.

Eğitim, ilk olarak ailede başlamakla beraber, sonrasında öğrenmenin gerçekleştiği kurumlar olan okullarda devam etmektedir. Okullar, sadece teorik bilginin öğrenildiği yerler değil aynı zamanda çocuğun ve ergenin birlikte yaşamayı öğrendiği, duygularını paylaştı̆̆ı, kendisini gerçekleştirdiği önemli sosyal kurumlardır. Ancak böyle önemli bir işlevi üstlen- 
miş olan okullar, eğitimde ölçülebilirliği sağlayabilmek ve sonuçlarıyla öğrencileri motive edebilmek adına, değerlendirme kriteri olarak notlama sistemine geçmiştir. Bu bağlamda, çocukların psiko-sosyal gelişiminde de çok önemli olan başarmak ve sonuçlarıyla mutlu olmanın göstergesi olan akademik başarı kavramı isteyerek veya istemeyerek sistemin merkezine oturtulmuştur. Bu durum çoğu zaman olumsuzlukları beraberinde getirmiştir.

Eğitim sistemindeki sorunlar ve okulların toplumsal sorunları silmesine yönelik beklentiler dikkate alındığında, sosyal hizmet uzmanları gibi meslek elemanlarınınokul sisteminin bir parçası olması şaşırtıcı değildir (Zastrow, 2013: 487). Ancak Türkiye de sosyal hizmetin, daha çok dezavantajlı gruplara yönelik olduğu algısı yaygındır. Oysa günün birçok saatini okulda geçiren bu dezavantajlı grupların, okullarda sosyal hizmet uzmanları aracılığıyla sosyal destek ve sosyal müdahale hizmetlerinden faydalanmasını sağlamak çok daha pratik ve davranışsal-ruhsal sağaltım açısından çok daha etkin çözümler getirecektir.

Akademik başarısılık veya okul başarısızlı̆̆ı gibi sorunlarda rehberlik ve danışmanlık faaliyetlerinin yanında sosyal destek sürecinin okul sosyal hizmeti aracılığıyla aktifleştirilmesi müracaatçılar lehinde önemli iyilik halleri sağlayacaktır. Eğitimin yapıldığı her bir kurumlarda sosyal çalışmacıların bulunması, sağlıklı sosyal destek ve sosyal müdahale hizmetleri için bir gerekliliktir.

Akademik başarı, bireyin psiko-motor ve duyuşsal gelişiminin dışında kalan, bütün program alanlarındaki davranış değişmelerini ifade eder (Erdogdu, 2006; akt. Keskin ve Sezgin, 2009: 5). Erkal'a (2013: 13) göre ise, öğrencilerin herhangi bir kurumdan mezun oldukları zaman sergilemiş oldukları performansın rakamsal olarak nota dönüşmüş halidir.

Akademik başarı, öğrencinin tanınmasında en etkili olan faktörlerden biridir. Eğitim sistemimizdeki uygulamada, var olan bilgileri aktarma ve teorik bilgiler verme ön plana çıkmaktadır. Bunun paralelinde temel akademik bilgiler ve temel akademik bilgilere sahip olunup olunmadığının değerlendirilmesinde akademik başarı önem kazanmaktadır. Öğrencinin ailesi ve çevresi tarafindan takdir edilmesi veya olumsuz anlamda yarg1- 


\section{$12 \cdot$ YALOVA SOSYAL BILIMLER DERGISI}

lanması, akademik başarı veya başarısızlığına bağlı olarak gerçekleşmektedir. OysaJung'un da vurguladığı gibi yaşam, hatalar ve başarısızlıklar olmadan tam bir yaşam olmamaktadır (Jung, 2012:272).Öğrencinin etiketlenmesinde bu kadar önemli rol oynayan, onun kendine güvenini sorgulatan, toplum tarafindan kabul görmesine kadar giden bir boyuta ulaşan akademik başarı kavramı, eğitim sisteminde önemli bir yer taşımaktadır. (Bahçetepe, 2013: 3).

Akademik başarısızlık, sadece aynı sınıfı bir kez daha tekrar eden ya da öğrenimini yarıda kesen öğrencilerle sınırlı kalmamaktadır. Sınıfta kalmadan öğrenimlerini tamamlayan öğrencilerinde, ciddi akademik sorunları olduğu söylenebilir (Can, 1992: 1). Akademik başarısızlık aynı zamanda adölesan çağın en büyük iki probleminden biri olarak kabul edilmektedir (Joseph vd., 1997: 729)

Akademik başarı konusunda yapılmış birçok ilgili araştırma mevcuttur:

Sekizinci sınıf öğrencilerinin akademik başarıları ile algıladıkları okul iklimi arasında anlamlı bir ilişkinin olup olmadığını incelemek amacıyla yapılan bir araştırmanın sonucunda, okul ikliminin Destekleyici Öğretmen Davranışları ve Başarı Odaklılık boyutları ile akademik başarı arasında olumlu yönde güçlü bir ilişki olduğu bulunmuştur(Bahçetepe, 2013). İlköğretim beşinci sınıf öğrencilerinin akademik başarılarının, öğretmenlerin empatik beceri düzeylerine göre farklılaşıp farklılaşmadığını tespit etmek ve ayrıca öğretmenlerin empatik becerileri ve öğrencilerin akademik başarıları ile ilişkili olabileceği düşünülen bazı değişkenleri incelemek amacıyla yapılan araştırma da elde edilen bulgular; öğrencilerin akademik başarılarının, öğretmenlerin empati becerilerine göre farklılaşmadığını göstermektedir (Yavaş, 2007). Erkal'ın (2013) akademik başarıyı etkileyen değişkenler üzerine yapmış olduğu araştırma sonuçları göre, öğrencilerin yaş grupları, anne öğrenim durumları, baba öğrenim durumları ve öğrencinin öğrenim gördüğü düzey değișkenlerine göre öğrencilerin akademik başarı puanları açısından bir farklılığın olduğu tespit edilmiştir. Yıldırım ve Ergene'nin (2003) araştırmasına göre, boyun eğici davranışlar ile akademik başarı arasında negatif yönde anlamlı ilişskiler bulunmuştur(Y1ldırım ve Ergene, 2003; akt. Kızıldağ, 2009: 42). 1980-1985 döneminde 
Ankara ilinde incelenen 27 çocuk intiharından 25'inin öğrenci, hatta büyük bir bölümünün ilkokul öğrencisi olduğu yine dikkat çeken bir araştırmadır. (Güçlü, 2001: 47).

$\mathrm{Bu}$ araştırmanın amacı, okul sosyal hizmeti perspektifinden lise kademesindeki öğrencilerin akademik başarı düzeylerinin bazı değişkenler açısından incelenmesidir. Bunun yanı sıra, akademik yönden başarısızlık sorunu yaşayan öğrencilere bu değişkenler dikkate alınarak okul sosyal hizmeti olarak neler sunulabilir bunu tartışmaktır.

Türkiye'de ve tüm gelişmiş toplumlarda akademik olarak başarılı ve nitelikli insan gücü, bir ülkenin ilerlemesinde en önemli güç olduğu kabul edilir. Bunun yanında çeşitli sebeplerle ortaya çıkabilecek olan akademik başarısızlıklar, okulu terk etme, yeteneği oranında başarı gösterememe,..v.b. gibi sorunlar okul sosyal hizmeti kapsamında ele alınacak sorunlardır. Yine öğrencinin bu sorunlarına yönelik sosyal, psikolojik ve eğitsel düzeyde çalışmalar yaparak öğrencinin en yüksek iyilik halini yakalamak sosyal hizmet uzmanının birincil görevlerindendir.

\section{Yöntem}

\subsection{Problem Cümlesi}

Lise kademesindeki öğrencilerin akademik başarı düzeylerinin bazı değişkenler açısından incelenmesi amacıyla yapılan bu araştırmada aşağıdaki sorulara yanıt aranmıştır.

1. Öğrencilerin cinsiyeti ve akademik başarı düzeyleri arasında anlamlı bir ilişki var mıdır?

2. Öğrencilerin yaşı ve akademik başarı düzeyleri arasında anlamlı bir ilişki var mıdır?

3. Öğrencilerin sınıf kademesi ve akademik başarı düzeyleri arasında anlamlı bir ilişki var mıdır?

4. Öğrencilerin sınıf mevcudu ve akademik başarı düzeyleri arasında anlamlı bir ilişki var mıdır?

5. Öğrencilerin anne babalarının evlilik durumu ve akademik başarı düzeyleri arasında anlamlı bir ilişki var mıdır? 


\section{$14 \cdot$ YALOVA SOSYAL BILIMLER DERGISI}

6. Öğrencilerin kardeş sayısı ve akademik başarı düzeyleri arasında anlamlı bir ilişki var mıdır?

7. Öğrencilerin ailede engelli birisi olup-olmama durumu ve akademik başarı düzeyleri arasında anlamlı bir ilişki var mıdır?

\subsection{Araştırmanın Modeli}

Araştırma, Bursa ili Gemlik ilçesindeki okullarda eğitim gören öğrencilerin görüşlerini betimlemeye yönelik olduğundan tarama modelindedir.

Tarama modeli, geçmişte ya da halen var olan bir durumu var olduğu biçimiyle betimlemeyi amaçlayan araştırma yaklaşımıdır. Tarama modelinde araştırmaya konu olan olay, birey ya da nesne, kendi koşulları içinde ve olduğu gibi tanımlanmaya çalışılır (Karasar, 2005; akt., Bahçetepe, 2013:86).

\subsection{Araştırmanın Evreni ve Örneklemi}

Araştırmanın çalışma evreni, Gemlik ilçesinde Milli Eğitim Bakanlığı'na bağlı yedi ortaöğretim kurumlarında okuyan lise öğrencilerinden oluşmaktadır. Araştırmada tüm çalışma evrenine ulaşma güçlüğ̈̈ nedeniyle örneklem alma yoluna gidilmiştir. Araştırmanın örneklemini belirlemek için tesadüfî (random) örnekleme yaklaşımı kullanılmıştır.

Her lisenin 9.,10.,11. ve 12. sınıfların her birinden tesadüfi yöntem ile seçilen şubelerinden toplam 665 öğrenciden, araştırma yapmak için örneklem grubu oluşturmuştur. Örneklem grubuna alınan okul türleri ve isimleri aşağıdaki gibi sıralanmıştır:

- Gemlik Celal Bayar Anadolu Lisesi

- Gemlik İmam Hatip Lisesi

- Gemlik Teknik ve Endüstri Meslek Lisesi

- Gemlik Kiz Meslek Lisesi

- Gemlik Ticaret Meslek Lisesi

- Gemlik Umurbey Sağlık Meslek Lisesi 


\subsection{Veri Toplama Araçları}

Araştırmada, öğrencilerin akademik başarılarını belirlemek için, bir y1l önceki ağırlıklı yılsonu ortalamaları, okul idarecilerinden e-okul sistemi aracılığı ile temin edilmiştir. Demografik bilgilerin öğrenilmesi için, araştırmacı tarafından geliştirilmiş olanKişisel Bilgi Formu kullanılmıştır.

Veri toplama araçları, araştırmacı tarafından bir araya getirilmiş, oluşturulan bir uygulama programı çerçevesinde belirlenen zamanlarda, araştırmaya katılan öğrencilere uygulanmıştır. Uygulama öncesinde, ilk olarak okul idarecilerinden e-okul sistemi aracılığ ile temin edilenağırlıklı yılsonu ortalamalarıyla sınıflara girilmiştir. Daha sonra Kişisel Bilgi Formu araştırmacı tarafından öğrencilere uygulanmış, ağırlıklı not ortalamasını hatırlayamayan öğrencilere e-okul çıktılarından ilgili öğrenciye ağırlıklı yıl sonu ortalaması söylenmiştir.

\subsection{Verilerin Analizi}

Araştırmada elde edilen veriler SPSS (Statistical Package for Social Sciences) for Windows 21.0 programı kullanılarak analiz edilmiştir. Veriler değerlendirilirken tanımlayıcı istatistiksel metotlar (Sayı, Yüzde, Ortalama, Standart sapma) kullanılmıştır.

Niteliksel gruplu değişkenlerin arasında Ki-Kare analizi uygulanmıştır. Elde edilen bulgular \%95 güven aralığında, \%5 anlamlılık düzeyinde değerlendirilmiştir.

\subsection{Bulgular}

Öğrencilerin demografik özelliklerine göre frekans ve yüzde oranları Tablo 1'de verilmiştir. 
Tablo 1. Öğrencilerin Demografik Özelliklerine İlişkin Bulgular

\begin{tabular}{|c|c|c|c|}
\hline Tablolar & Gruplar & Frekans(n) & $\begin{array}{c}\text { Yüzde } \\
(\%)\end{array}$ \\
\hline \multirow{3}{*}{ Cinsiyet } & $\mathrm{K} 1 \mathrm{z}$ & 389 & 58,5 \\
\hline & Erkek & 276 & 41,5 \\
\hline & Toplam & 665 & 100 \\
\hline \multirow{5}{*}{ Sinif Kademesi } & 9 & 195 & 29,3 \\
\hline & 10 & 162 & 24,4 \\
\hline & 11 & 175 & 26,3 \\
\hline & 12 & 133 & 20 \\
\hline & Toplam & 665 & 100 \\
\hline \multirow{4}{*}{ Sinif Mevcudu } & $1-15$ & 13 & 2 \\
\hline & $16-25$ & 179 & 26,9 \\
\hline & $26-35$ & 473 & 71,1 \\
\hline & Toplam & 665 & 100 \\
\hline \multirow{6}{*}{ Akademik Başarı Düzeyi } & $0-25$ & 3 & 0,5 \\
\hline & $26-50$ & 27 & 4,1 \\
\hline & $51-75$ & 340 & 51,1 \\
\hline & 76-85 & 189 & 28,4 \\
\hline & $86-100$ & 106 & 15,9 \\
\hline & Toplam & 665 & 100 \\
\hline \multirow{4}{*}{ Evlilik Durumu } & Evliliği devam ediyor & 627 & 94,3 \\
\hline & Boşandılar & 32 & 4,8 \\
\hline & \begin{tabular}{|l}
$\begin{array}{l}\text { Boşanmadılar ama } \\
\text { yaşıorlar }\end{array}$ \\
\end{tabular} & 6 & 0,9 \\
\hline & Toplam & 665 & 100 \\
\hline \multirow{6}{*}{ Kardeş Sayısı } & Tek çocuk & 38 & 5,7 \\
\hline & 2 & 322 & 48,4 \\
\hline & 3 & 210 & 31,6 \\
\hline & 4 & 62 & 9,3 \\
\hline & 5 Ve üstü & 33 & 5 \\
\hline & Toplam & 665 & 100 \\
\hline
\end{tabular}


OKUL SOSYAL HIZMETI PERSPEKTIFINDEN LISE ÖĞRENCILERININ AKADEMIK BAŞARI DÜZEYLERININ FARKLI DEĞIŞKENLER AÇISINDAN INCELENMESI • 17

\begin{tabular}{|l|l|l|l|}
\hline \multirow{4}{*}{$\begin{array}{l}\text { AiledeEngelliOlup-Olmama } \\
\text { Durumu }\end{array}$} & Engelli yok & 630 & 94,7 \\
\cline { 2 - 4 } & Anne & 2 & 0,3 \\
\cline { 2 - 4 } & Baba & 10 & 1,5 \\
\cline { 2 - 4 } & Kardeşim & 4 & 0,6 \\
\cline { 2 - 4 } & Diğer & 19 & 2,9 \\
\cline { 2 - 4 } & Toplam & 665 & 100 \\
\hline
\end{tabular}

\subsection{1. Öğrencilerin Akademik Başarıları Düzeylerinin Cinsiyet Açısından İncelenmesine Yönelik Bulgular}

Öğrencilerin akademik başarıları düzeylerinin cinsiyet değişkeni açısından incelenmesine yönelik elde edilen bulguların istatistiksel analizi Tablo 2'deverilmiştir.

Tablo 2. Öğrencilerin Cinsiyete Göre Akademik Başarı Düzeylerinin Incelenmesi

\begin{tabular}{|c|c|c|c|c|c|c|c|c|c|c|c|c|c|}
\hline \multirow{3}{*}{ Cinsiyet } & \multicolumn{10}{|c|}{ Akademik Başarı Düzeyi } & & & \multirow{3}{*}{$\mathbf{X}^{2} / \mathbf{p}$} \\
\hline & \multicolumn{2}{|c|}{\begin{tabular}{|l|}
$0-25$ \\
\end{tabular}} & \multicolumn{2}{|c|}{$26-50$} & \multicolumn{2}{|c|}{$51-75$} & \multicolumn{2}{|c|}{\begin{tabular}{|l|}
$76-85$ \\
\end{tabular}} & \multicolumn{2}{|c|}{$86-100$} & \multicolumn{2}{|c|}{ Toplam } & \\
\hline & n & $\%$ & n & $\%$ & n & $\%$ & $\mathbf{n}$ & $\%$ & n & $\%$ & n & $\%$ & \\
\hline Kız & 1 & $\% 33,3$ & 13 & $\% 48,1$ & 172 & $\% 50,6$ & 124 & $\% 65,6$ & 79 & $\% 74,5$ & 389 & $\% 58,5$ & \multirow{3}{*}{$\begin{array}{l}x^{2}=25,891 \\
p=0,000\end{array}$} \\
\hline Erkek & 2 & $\% 66,7$ & 14 & $\% 51,9$ & 168 & $\% 49,4$ & 65 & $\% 34,4$ & 27 & $\% 25,5$ & 276 & $\% 41,5$ & \\
\hline Toplam & 3 & $\% 100,0$ & 27 & $\% 100,0$ & 340 & $\% 100,0$ & 189 & $\% 100,0$ & 106 & $\% 100,0$ & 665 & $\% 100,0$ & \\
\hline
\end{tabular}

Cinsiyet ile akademik başarı düzeyi arasında anlamlı ilişki bulunmuştur $\left(X^{2}=25,891 ; p=0,000<0.05\right)$.

\subsection{2. Öğrencilerin Akademik Başarıları Düzeylerinin Sınıf Kademesi Açısından İncelenmesine Yönelik Bulgular}

Öğrencilerin akademik başarıları düzeylerinin sınıf kademesi değişkeni açısından incelenmesine yönelik elde edilen bulguların istatistiksel analizi Tablo 4'de verilmiştir. 
$18 \cdot$ YALOVA SOSYAL BILIMLER DERGISI

Tablo 3. Öğrencilerin Sınıf Kademesine Göre Akademik Başarı Düzeylerinin Incelenmesi

\begin{tabular}{|c|c|c|c|c|c|c|c|c|c|c|c|c|c|}
\hline \multirow{3}{*}{$\begin{array}{l}\text { Sinıf } \\
\text { Kademesi }\end{array}$} & \multicolumn{10}{|c|}{ Akademik Başarı Düzeyi } & & & \multirow{3}{*}{$\mathbf{X}^{2} / \mathbf{p}$} \\
\hline & \multicolumn{2}{|c|}{$0-25$} & \multicolumn{2}{|c|}{$26-50$} & \multicolumn{2}{|c|}{$51-75$} & \multicolumn{2}{|c|}{$76-85$} & \multicolumn{2}{|c|}{$86-100$} & \multicolumn{2}{|c|}{ Toplam } & \\
\hline & $\mathbf{n}$ & $\%$ & n & $\%$ & $\mathbf{n}$ & $\%$ & $\mathbf{n}$ & $\%$ & $\mathbf{n}$ & $\%$ & $\mathbf{n}$ & $\%$ & \\
\hline 9 & 2 & $\% 66,7$ & 11 & $\% 40,7$ & 75 & $\% 22,1$ & 49 & $\% 25,9$ & 58 & $\% 54,7$ & 195 & $\% 29,3$ & \multirow{5}{*}{$\begin{array}{l}X^{2}=87,225 \\
p=0,000\end{array}$} \\
\hline 10 & 1 & $\% 33,3$ & 9 & $\% 33,3$ & 114 & $\% 33,5$ & 33 & $\% 17,5$ & 5 & $\% 4,7$ & 162 & $\% 24,4$ & \\
\hline 11 & 0 & $\% 0,0$ & 2 & $\% 7,4$ & 99 & $\% 29,1$ & 58 & $\% 30,7$ & 16 & $\% 15,1$ & 175 & $\% 26,3$ & \\
\hline 12 & 0 & $\% 0,0$ & 5 & $\% 18,5$ & 52 & $\% 15,3$ & 49 & $\% 25,9$ & 27 & $\% 25,5$ & 133 & $\% 20,0$ & \\
\hline Toplam & 3 & $\% 100,0$ & 27 & $\% 100,0$ & 340 & $\% 100,0$ & 189 & $\% 100,0$ & 106 & $\% 100,0$ & 665 & $\% 100,0$ & \\
\hline
\end{tabular}

Sınıf kademesi ile akademik başarı düzeyi arasında anlamlı ilişki bulunmuştur $\left(\mathrm{X}^{2}=87,225 ; \mathrm{p}=0,000<0.05\right)$.

\subsection{3. Öğrencilerin Akademik Başarıları Düzeylerinin Anne Babalarının Evlilik Durumu Açısından İncelenmesine Yönelik Bulgular}

Öğrencilerin akademik başarıları düzeylerinin anne babalarının evlilik durumu değişkeni açısından incelenmesine yönelik elde edilen bulguların istatistiksel analizi Tablo5'de verilmişstir.

Tablo 4. Öğrencilerin Anne Babalarının Evlilik Durumuna Göre Akademik Başarı Düzeylerinin Incelenmesi

\begin{tabular}{|c|c|c|c|c|c|c|c|c|c|c|c|c|c|}
\hline \multirow{3}{*}{$\begin{array}{l}\text { Anne } \\
\text { Babaların } \\
\text { Evlilik } \\
\text { Durumları }\end{array}$} & \multicolumn{10}{|c|}{ Akademik Başarı Düzeyi } & & & \multirow{3}{*}{$\mathbf{X}^{2} / \mathbf{p}$} \\
\hline & \multicolumn{2}{|c|}{$0-25$} & \multicolumn{2}{|c|}{$26-50$} & \multicolumn{2}{|c|}{$51-75$} & \multicolumn{2}{|c|}{ 76-85 } & \multicolumn{2}{|c|}{$86-100$} & \multicolumn{2}{|c|}{ Toplam } & \\
\hline & n & $\%$ & n & $\%$ & n & $\%$ & n & $\%$ & n & $\%$ & n & $\%$ & \\
\hline $\begin{array}{l}\text { Evliliği } \\
\text { devam ediyor }\end{array}$ & 2 & $\% 66,7$ & 26 & $\% 96,3$ & 315 & $\% 92,6$ & 182 & $\% 96,3$ & 102 & $\% 96,2$ & 627 & $\% 94,3$ & \multirow{4}{*}{$\begin{array}{l}X^{2}=40,040 \\
p=0,000\end{array}$} \\
\hline Boşandılar & 0 & $\% 0,0$ & 1 & $\% 3,7$ & 21 & $\% 6,2$ & 6 & $\% 3,2$ & 4 & $\% 3,8$ & 32 & $\% 4,8$ & \\
\hline $\begin{array}{l}\text { Boşanmadilar } \\
\text { ama ayrı } \\
\text { yașiyorlar }\end{array}$ & 1 & $\% 33,3$ & 0 & $\% 0,0$ & 4 & $\% 1,2$ & 1 & $\% 0,5$ & 0 & $\% 0,0$ & 6 & $\% 0,9$ & \\
\hline Toplam & 3 & $\% 100,0$ & 27 & $\% 100,0$ & 340 & $\% 100,0$ & 189 & $\% 100,0$ & 106 & $\% 100,0$ & 665 & $\% 100,0$ & \\
\hline
\end{tabular}

Öğrencilerin anne babalarının evlilik durumu ile akademik başarı düzeyleri arasında anlamlı ilişki bulunmuştur $\left(X^{2}=40,040 ; p=0,000<0.05\right)$. 


\subsection{4. Öğrencilerin Akademik Başarıları Düzeylerinin Kardeş Sayısı Açısından İncelenmesine Yönelik Bulgular}

Öğrencilerin akademik başarıları düzeylerinin kardeş sayısı değişkeni açısından incelenmesine yönelik elde edilen bulguların istatistiksel analizi Tablo 6 'da verilmiştir.

Tablo 5. Öğrencilerinin Kardeş Sayısına Göre Akademik Başarı Düzeylerinin Incelenmesi

\begin{tabular}{|c|c|c|c|c|c|c|c|c|c|c|c|c|c|}
\hline \multirow{3}{*}{$\begin{array}{l}\text { Kardeş } \\
\text { Sayısı }\end{array}$} & \multicolumn{10}{|c|}{ Akademik Başarı Düzeyi } & & & \multirow{3}{*}{$\mathbf{X}^{2} / \mathbf{p}$} \\
\hline & \multicolumn{2}{|c|}{$0-25$} & \multicolumn{2}{|c|}{$26-50$} & \multicolumn{2}{|c|}{$51-75$} & \multicolumn{2}{|c|}{$76-85$} & \multicolumn{2}{|c|}{$86-100$} & \multicolumn{2}{|c|}{ Toplam } & \\
\hline & n & $\%$ & n & $\%$ & n & $\%$ & n & $\%$ & n & $\%$ & n & $\%$ & \\
\hline \begin{tabular}{|l|} 
Tek \\
çocuk
\end{tabular} & 1 & $\% 33,3$ & 1 & $\% 3,7$ & 19 & $\% 5,6$ & 12 & $\% 6,3$ & 5 & $\% 4,7$ & 38 & $\% 5,7$ & \multirow{6}{*}{$\begin{array}{l}X^{2}=30,247 \\
p=0,017\end{array}$} \\
\hline 2 & 0 & $\% 0,0$ & 11 & $\% 40,7$ & 162 & $\% 47,6$ & 94 & $\% 49,7$ & 55 & $\% 51,9$ & 322 & $\% 48,4$ & \\
\hline 3 & 1 & $\% 33,3$ & 8 & $\% 29,6$ & 115 & $\% 33,8$ & 54 & $\% 28,6$ & 32 & $\% 30,2$ & 210 & $\% 31,6$ & \\
\hline 4 & 0 & $\% 0,0$ & 2 & $\% 7,4$ & 25 & $\% 7,4$ & 24 & $\% 12,7$ & 11 & $\% 10,4$ & 62 & $\% 9,3$ & \\
\hline \begin{tabular}{|l|}
$5 \mathrm{ve}$ \\
üstü \\
\end{tabular} & 1 & $\% 33,3$ & 5 & $\% 18,5$ & 19 & $\% 5,6$ & 5 & $\% 2,6$ & 3 & $\% 2,8$ & 33 & $\% 5,0$ & \\
\hline Toplam & 3 & $\% 100,0$ & 27 & $\% 100,0$ & 340 & $\% 100,0$ & 189 & $\% 100,0$ & 106 & $\% 100,0$ & 665 & $\% 100,0$ & \\
\hline
\end{tabular}

Kardeş sayısı ile akademik başarı düzeyleri arasında anlamlı ilişki bulunmuştur $\left(X^{2}=30,247 ; p=0,017<0.05\right)$.

\subsection{5. Öğrencilerin Akademik Başarıları Düzeylerinin Ailede Engelli Birisi Olup-Olmama Durumu Açısından İncelenmesine Yönelik Bulgular}

Öğrencilerin akademik başarıları düzeylerinin ailede engelli birisi olup-olmama durumudeğişkeni açısından incelenmesine yönelik elde edilen bulguların istatistiksel analizi Tablo 7'de verilmiştir. 
$20 \cdot$ YALOVA SOSYAL BILIMLER DERGISI

Tablo 6. Ö̆̆rencilerin Ailede Engelli Birisi Olup-Olmama Durumuna Göre Akademik Başarı Düzeylerinin Incelenmesi

\begin{tabular}{|c|c|c|c|c|c|c|c|c|c|c|c|c|c|}
\hline \multirow{3}{*}{$\begin{array}{l}\text { Ailedeki } \\
\text { Engellilik } \\
\text { Durumu }\end{array}$} & \multicolumn{10}{|c|}{ Akademik Başarı Düzeyi } & & & \multirow{3}{*}{$\mathrm{X}^{2} / \mathrm{p}$} \\
\hline & \multicolumn{2}{|c|}{$0-25$} & \multicolumn{2}{|c|}{$26-50$} & \multicolumn{2}{|c|}{$51-75$} & \multicolumn{2}{|c|}{$76-85$} & \multicolumn{2}{|c|}{$86-100$} & \multicolumn{2}{|c|}{ Toplam } & \\
\hline & n & $\%$ & n & $\%$ & n & $\%$ & n & $\%$ & n & $\%$ & n & $\%$ & \\
\hline $\begin{array}{l}\text { Engelli } \\
\text { yok }\end{array}$ & 3 & $\% 100,0$ & 23 & $\% 85,2$ & 320 & $\% 94,1$ & 183 & $\% 96,8$ & 101 & $\% 95,3$ & 630 & $\% 94,7$ & \multirow{6}{*}{$\begin{array}{l}X^{2}=15,654 \\
p=0,477\end{array}$} \\
\hline Anne & 0 & $\% 0,0$ & 0 & $\% 0,0$ & 2 & $\% 0,6$ & 0 & $\% 0,0$ & 0 & $\% 0,0$ & 2 & $\% 0,3$ & \\
\hline Baba & 0 & $\% 0,0$ & 1 & $\% 3,7$ & 5 & $\% 1,5$ & 3 & $\% 1,6$ & 1 & $\% 0,9$ & 10 & $\% 1,5$ & \\
\hline Kardeşim & 0 & $\% 0,0$ & 0 & $\% 0,0$ & 1 & $\% 0,3$ & 2 & $\% 1,1$ & 1 & $\% 0,9$ & 4 & $\% 0,6$ & \\
\hline Diğer & 0 & $\% 0,0$ & 3 & $\% 11,1$ & 12 & $\% 3,5$ & 1 & $\% 0,5$ & 3 & $\% 2,8$ & 19 & $\% 2,9$ & \\
\hline Toplam & 3 & $\% 100,0$ & 27 & $\% 100,0$ & 340 & $\% 100,0$ & 189 & $\% 100,0$ & 106 & $\% 100,0$ & 665 & $\% 100,0$ & \\
\hline
\end{tabular}

Öğrencilerin ailelerinde engelli birisi olup-olmama durumu ile akademik başarı düzeyleri arasında anlamlı ilişki bulunmamıştır $\left(X^{2}=15,654 ; p=0,477>0.05\right)$.

\section{Sonuç ve Öneriler}

$\mathrm{Bu}$ bölümde araştırmanın bulgularına yönelik sonuçlar ortaya konmuş ve bu sonuçlara yönelik öneriler geliştirilmiştir.

\section{Sonuç}

Lise kademesinde öğrenim gören öğrencilerin akademik başarıları düzeyleriyle bazı değişkenlerin arasında anlamlı bir ilişki olup olmadığını incelemek amacıyla yapılan araştırmada şu sonuçlara ulaşılmıştır.

Araştırmanın ilk alt problemi, öğrencilerin akademik başarıları ile cinsiyeti arasında bir ilişki olup olmadığına yöneliktir. Tablo 2'den yola çıkarak yapılan istatistiki analize göre, cinsiyet ile akademik başarı düzeyleri arasında anlamlı bir ilişkinin olduğu bulunmuştur. Buna göre kız öğrencilerin akademik başarı düzeyleri, erkek öğrencilerin akademik başarı düzeylerine göre daha yüksektir. Kızıldağ'ın (2009) yetiştirme yurdunda 
kalan ve ailesiyle yaşayan öğrenciler üzerinde yaptığı araştırma sonuçları, elde edilen sonuçları desteklemektedir.

Araştırmanın ikinci alt hipotezi, öğrencilerin akademik başarıları ile sınıf kademeleri arasında ilişki olup olmadığına yöneliktir. Tablo 3'dan yola çıkılarak yapılan istatistiki analize göre, sınıf kademeleri ile akademik başarı düzeyleri arasında anlamlı bir ilişkinin olduğu bulunmuştur. Buna göre, ara kademelerdeki öğrencilerin akademik başarı düzeyleri, 9. ve 12. sınıftaki öğrencilerin akademik başarı düzeylerine göre daha yüksektir. Erkal'ın (2013) ve Aktan'ın (2012) öğrenciler üzerinde akademik başarıyı etkileyen etmenlerle ilgili olarak yaptıkları araştırmaların sonuçları, elde edilen sonuçları desteklemektedir.

Araştırmanın üçüncü alt problemi, öğrencilerin akademik başarıları ile anne babalarının evlilik durumu arasında ilişki olup olmadığına yöneliktir. Tablo 4'den yola çıkılarak yapılan istatistiki analize göre, anne babanın evlilik durumu ile akademik başarı düzeyleri arasında anlamlı bir ilişkinin olduğu bulunmuştur. Buna göre, anne babası boşanmış veya anne babası boşanmadan ayrı yaşayan öğrencilerin akademik başarı düzeyleri genellikle düşük olduğu ortaya çıkmıştır. Güney'in (2009) ilköğretim öğrencileri ile yaptığı araştırma, Yıldırım ve Ergene'nin (2003) boyun eğici davranışlar ile akademik başarı arasındaki ilişki üzerine yaptığ 1 araştırmalar, elde edilen sonuçları desteklemektedir (akt. Kızıldağ, 2009: 42).

Araştırmanın dördüncü alt problemi, öğrencilerin akademik başarıları ile kardeş sayıları arasında ilişki olup olmadığına yöneliktir. Tablo 5'den yola çıkılarak yapılan istatistiki analize göre, kardeş sayısı ile akademik başarı düzeyleri arasında anlamlı bir ilişkinin olduğu bulunmuştur. Buna göre, kardeş sayısı tek çocuk, 4 kardeş veya 5 kardeş ve üstü olan öğrencilerin akademik başarıları düşmekte, 2 kardeş ve 3 kardeş olan öğrencilerin akademik başarıları artmaktadır. Coşkun ve Ünal'ın (2003) kültürel sermaye ve akademik başarı arasındaki ilişkiyi belirlemeye yönelik olarak 970 lise öğrencisi ile yürüttüğü araştırma sonuçları, elde edilen sonuçları desteklemektedir. (Coşkun ve Ünal, 2003; akt. Polat, 2008: 49).

Araştırmanın beşinci alt hipotezi, öğrencilerin akademik başarıları ile ailede engelli birisi olup-olmama durumu arasında ilişki olup olmadığına 
yöneliktir. Tablo 6'dan yola çıkılarak yapılan istatistiki analize göre, ailede engelli birisi olup-olmama durumu ile öğrencilerin akademik başarı düzeyleri arasında anlamlı bir ilişkinin olmadığı görülmüştür ( $p>0.05)$. Buna göre, ailede engelli birisinin olup-olmaması, öğrencilerin akademik başarı düzeylerini manidar olarak etkilememektedir.

\section{Öneriler}

\section{Sosyal Hizmet Uygulamalarına Yönelik Öneriler}

Yapılan bu araştırmada, öğrencilerin akademik başarı düzeyleri ile anlamlı düzeyde ilişkileri olan bazı değişkenler ortaya konmuştur.

Okullarda yaşanmakta olan akademik başarısızlık ve bunun gizil olarak etkileyebileceği farklı sosyal sonuçlar, yine bu doğrultuda sağlıklı piko-sosyal müdahaleleri ve sosyal destek süreçlerini gerekli kılmaktadır. Öğrencilerin okul hayatı boyunca, kendini gerçekleştirme süreçlerinde bu ve benzeri sorunlarla baş edebilmek için multidisipliner bir çalışmanın da gereği olarak okul sosyal çalışmacıların istihdamı tartışılmalı, farklı kurum ve kademelerde istihdamı gündeme alınmalıdır.

Sosyal çalışmacıların, okullarda verimli ve etkin olabilmesi, okul rehberlik servisinde görevli rehber öğretmenler ile mesleki çatışma yaşamaması için görev tanımlaması net olarak yapılmalıdır.

Daha çok dezavantajlı gruplara yönelik hizmetler olarak algılanan sosyal çalışma, aslında dezavantajlı gruplarında bulunduğu, eğitim gördüğü okullardan uzak kalması bu algının yerleşmesinin sebebi olmuştur. Okul sosyal hizmetinin eğitimde yerini alması sosyal hizmet mesleğinin daha çok tanınmasına ve daha çok bireyin hizmet almasına sebep olacaktır. Okul sosyal çalışmacısı diğer kurumlarda çalışan sosyal çalışmacılara göre bulunduğu pozisyon itibariyle okullarda çok daha avantajlı konumda olacaktır.

Okullarda yaşanan sorunlara yönelik gerçekleştirilecek mesleki müdahale, multidisipliner bir anlayışla oluşturulan sosyal servislerde daha etkin ve kalıcı çözümler getirecektir.

YIL: 6 SAYI: 11 
Okul sosyal hizmeti Türkiye'de yeteri kadar tanınmamaktadır. Bu sahada yapılacak her çalışma, mesleğin tanınmasına da ayrıca hizmet edecektir.

\section{Ulaşılan Sonuçlara Yönelik Öneriler}

$\mathrm{Bu}$ araştırmada,erkek öğrencilerin akademik başarı düzeylerinin kız öğrencilerden daha düşük olduğu görülmüştür. Bu bağlamda erkek öğrencilere yönelik olarak boş zamanı değerlendirme, serbest zaman kullanımı gibi beceriler kazandırılmaya çalışılabilir. Ayrıca etkili ve verimli ders çalışma yöntem ve tekniklerinin yanında karar verme ve sorumluluk alma becerisine yönelik grupla sosyal çalışmaya ağırlık verilebilir.

Yine araştırmada, akademik başarısızlığın 9. ve 12. sınıflarda belirginleştiği ortaya çıkmıştır. Öğrencilere yönelik sosyal çalışmacılar ve rehber öğretmenler tarafından bu kademe geçişlerinde bireysel çalışmalar yapılarak farkındalık düzeyleri artırılmalıdır.

Boşanan veya boşanmasa da ayrı yaşayan anne babaların mevcut evlilik durumlarının, öğrencilerin akademik başarılarını düşürdüğü görülmüştür. Parçalanmış ailelerden gelen öğrencilerin tespit edilmesi ve sosyal çalışmacılar tarafindan sosyal destek sürecine dahil edilmesi, öğrencilerin akademik başarısını artıracaktır.

\section{Araştırmacılara Yönelik Öneriler}

$\mathrm{Bu}$ araştırma, 2013-2014 eğitim öğretim yılı içinde Bursa ilinin Gemlik ilçesinde MEB'e bağlı resmi devlet okullarında öğrenim gören lise öğrencileri üzerinde yapılmıştır. Bu konuda yapılacak yeni araştırmalar, Türkiye'nin diğer bölgelerini kapsayacak şekilde geliştirilebilir.

Araştırmada yer alan değişkenlerin dışında farklı değişkenlerle, bu konuda yeni çalışmalar yapılabilir.

Araştırma MEB'e bağlı resmi eğitim kurumları dışında özel eğitim kurumlarında da uygulanarak kapsam genişletilebilir. Böylece özellikle bazı değişkenler açısından karşılaştırma yapılabilir. 


\section{KAYNAKÇA}

AKTAN, S. (2012) Öğrencilerin Akademik Başarısı, Özdüzenleme Becerisi, Motivasyonu ve Öğretmenlerin Öğretim Stilleri Arasında İlişki, Doktora Tezi, Balıkesir Üniversitesi Eğitim Bilimleri Enstitüsü.

BAHÇETEPE, Ü. (2013)“İlköğretim Sekizinci Sınıf Öğrencilerinin Akademik Başarıları İle Algıladıkları Okul İklimi Arasındaki İlişki”, Yüksek Lisans Tezi,İstanbul Üniversitesi Sosyal Bilimler Enstitüsü.

CAN, G. (1992)Akademik Başarısızlık ve Önlenmesi, Anadolu Üniversitesi Öğrencileri Üzerinde Bir Araştırma,Anadolu Üniversitesi Eğitim Fakültesi Yayınları No:23, Eskişehir.

ERKAL, C. (2013)“Ailesi Parçalanmış Olan İlkokul, Ortaokul ve Lise Öğrencilerinin Çeşitli Değişkenlere Göre Okul Başarısı Düzeylerinin İncelenmesi”, Yüksek Lisans Tezi, Sakarya Üniversitesi Eğitim Bilimleri Enstitüsü.

GLASSER, W. (1999)Başarısızlığın Olmadı̆̆ı Okul (Çev. KıvılcımTeksöz), Beyaz Yayınları, İstanbul.

GÜÇLÜ, F. (2001)İntihar Umutsuzluğun Tırmanışı.(3. Baskı), SABEV Yayınla$\mathrm{r} 1$, Ankara.

GÜNEY, Ü. (2009)“İlköğretim Okulu Öğrencilerinin Akademik Başarıları İle Algılanan Aile Yapısı Arasındaki İlişkilerinin İncelenmesi”, Yüksek Lisans Tezi, Yeditepe Üniversitesi Sosyal Bilimler Enstitüsü.

JOSEPH P. A., PHILLIBER S., HERRLING S. veKUPERMINC G. P. (1997) Preventing Teen Pregnancy and Academic Failure: Experimental Evalution of a Developmentally Based Approach, Child Development, 64. (4), August, s. 729-742.

JUNG, C. G. (2012)Anılar, Düşler, Düşünceler (Çev. İris Kantemir), Can Sanat Yayınları, İstanbul.

KESKIN, G. ve SEZGIN B. (2009)Bir Grup Ergende Akademik Başarı Durumuna Etki Eden Etmenlerin Belirlenmesi, Fırat Sağlık Hizmetleri Dergisi, 4. (10), s. 3-18.

YIL: 6 SAYI: 11 
KIZILDAĞ, S. (2009)“Akademik Başarının Yordayıcısı Olarak Yalnızlık, Boyun Eğici Davranışlar ve Sosyal Destek”, Yüksek Lisans Tezi, Hacettepe Üniversitesi Sosyal Bilimler Enstitüsü.

POLAT, S. (2008), “Akademik Başarının Yordayıcısı Olarak Yalnızlık, Sınav Kaygısı ve Sosyal Destek, Eğitim Bilim Toplum Dergisi”, Cilt:7, Say1: 25, Kış: 2008-2009, s. 46-61

YAVAŞ, B. (2007)“i̇lköğretim Beşinci Sınıf Öğretmenlerinin Empati Becerileri İle Öğrencilerinin Akademik Başarılarının Arasındaki İlişki, Yüksek Lisans Tezi”, Marmara Üniversitesi Eğitim Bilimleri Enstitüsü.

YILMAZ, M. G. (2012)“Ortaöğretim Öğrencilerinin Yalnızlık Düzeyleri İle Utangaçlık Düzeyleri Arasındaki İlişki, Yüksek Lisans Tezi”, Yeditepe Üniversitesi Sosyal Bilimler Enstitüsü.

ZASTROW, C. (2013).Sosyal Hizmete Girişs (Çev. Editörü Durdu Baran Çiftçi), Nika Yayınevi, Ankara. 